\title{
Editorial
}

\section{Development of Camptotheca Decaisne as Pharmaceutical Crops}

\author{
Shiyou $\mathrm{Li}^{*}$
}

National Center for Pharmaceutical Crops, Arthur Temple College of Forestry and Agriculture, Stephen F. Austin State University, Nacogdoches, TX 75962, USA

Camptotheca Decaisne is a genus of the family Nyssaceae native to China. It is the major natural source of camptothecins (CPTs), anti-cancer alkaloids. CPTs (Fig. 1) have shown promising anti-cancer activity in almost all kinds of cancer in clinical trials in the USA, China, Japan, and Europe since 1957, and especially those since 1986 [1]. The CPT agents have also shown potent anti-viral activity against HIV in both animal and human cell cultures [2]. In 1996, Topotecan (TPT, Hycamtin ${ }^{\circledR}$ ) and Irinotecan (CPT-11, Camptosar $^{\circledR}$ ), two semi-synthetic CPT drugs were approved by the FDA for the treatment of patients with advanced ovarian and colon cancer, respectively. In 1998, Topotecan was approved by the FDA for treatment of small cell lung cancer. 9-Nitrocamptothecin (9-NC, Rubitecan), 9Aminocamptothecin (9-AC) and several other CPT analogs (e.g., CZ112) also show promising results in clinical trials. In fact, CPT agents have been recognized as the most promising anti-cancer drugs in the world. Therefore, worldwide demand for CPTs is dramatically increasing. Currently, CPT production is still dependent on natural supply. However, Camptotheca trees grow rapidly, and many parts of the tree can be used to extract drug CPTs.

The earliest record of the Camptotheca tree dated back to 1848 in the Chinese book, Zhi Wu Ming Shi Tu Kao [1]. Until 1965, when CPT was first isolated from Camptotheca [3], only 25 publications were available worldwide on Camptotheca; and all of these to treating only botanical aspects [1]. By February 2000, 540 patents had been granted worldwide and approximately1,500 journal articles had been published. Over $95 \%$ of the publications, however, dealt with either chemical or medical aspects of CPTs with only about $5 \%$ focusing on the Camptotheca tree, itself. Principal research studies on Camptotheca taxonomy [4-6], anatomy and morphology [1, 7-10], phylogeny [11-13], embryology [14], chromosome numbers [15], pollination biology [14, 16, 17], geography $[1,18,19]$, and physiology [20-22].

*Address correspondence to this author at the National Center for Pharmaceutical Crops, Arthur Temple College of Forestry and Agriculture, Stephen F. Austin State University, Nacogdoches, TX 75962, USA;

Tel: 936-468-2071; Fax: 936-468-7058;

E-mail: lis@sfasu.edu

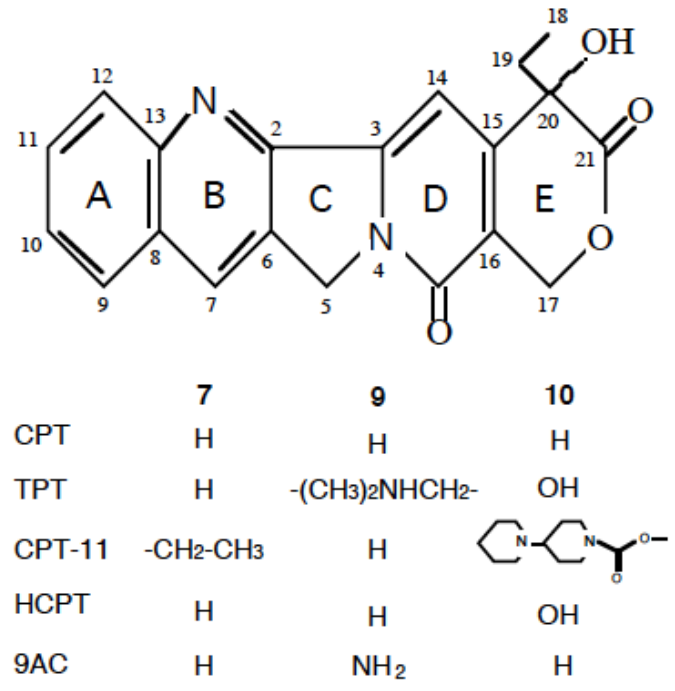

Fig. (1). Chemical structure of camptothecin (CPT) and its main derivatives as anti-cancer drugs in clinical treatments and trials.

Obviously, a systematic study of Camptotheca as pharmaceutical crops for production of CPTs is needed. Theoretically, taxonomic and genetic diversity, and CPT production ecology are still poorly understood. Our studies have identified at least three problems with the development of Camptotheca as a source for CPTs. First, Camptotheca is an endangered genus whose wild populations may possibly be nearing extinction. Second, the gene pool of Camptotheca in the USA is extremely small. Most of the trees in the USA are traceable to only two mature trees in Chico, California, that germinated from seeds imported from southern China in 1934. Selfing is often the only natural breeding system for the Camptotheca trees in USA; and these offsprings are normally of low quality. In addition, asexual propagation is the method commonly used to reproduce Camptotheca seedlings in the USA. Third, cold-hardiness and droughttolerance are two major problems in the development of plantations in the southeastern USA. The present genetic resource base of Camptotheca in the USA is too small to select for either cold-hardiness, drought-tolerance, or highCPT-yielding genotypes. 


\section{Evaluation of Potential of CPTs as Anti-cancer and Anti-viral Drugs}

(1993-1994)

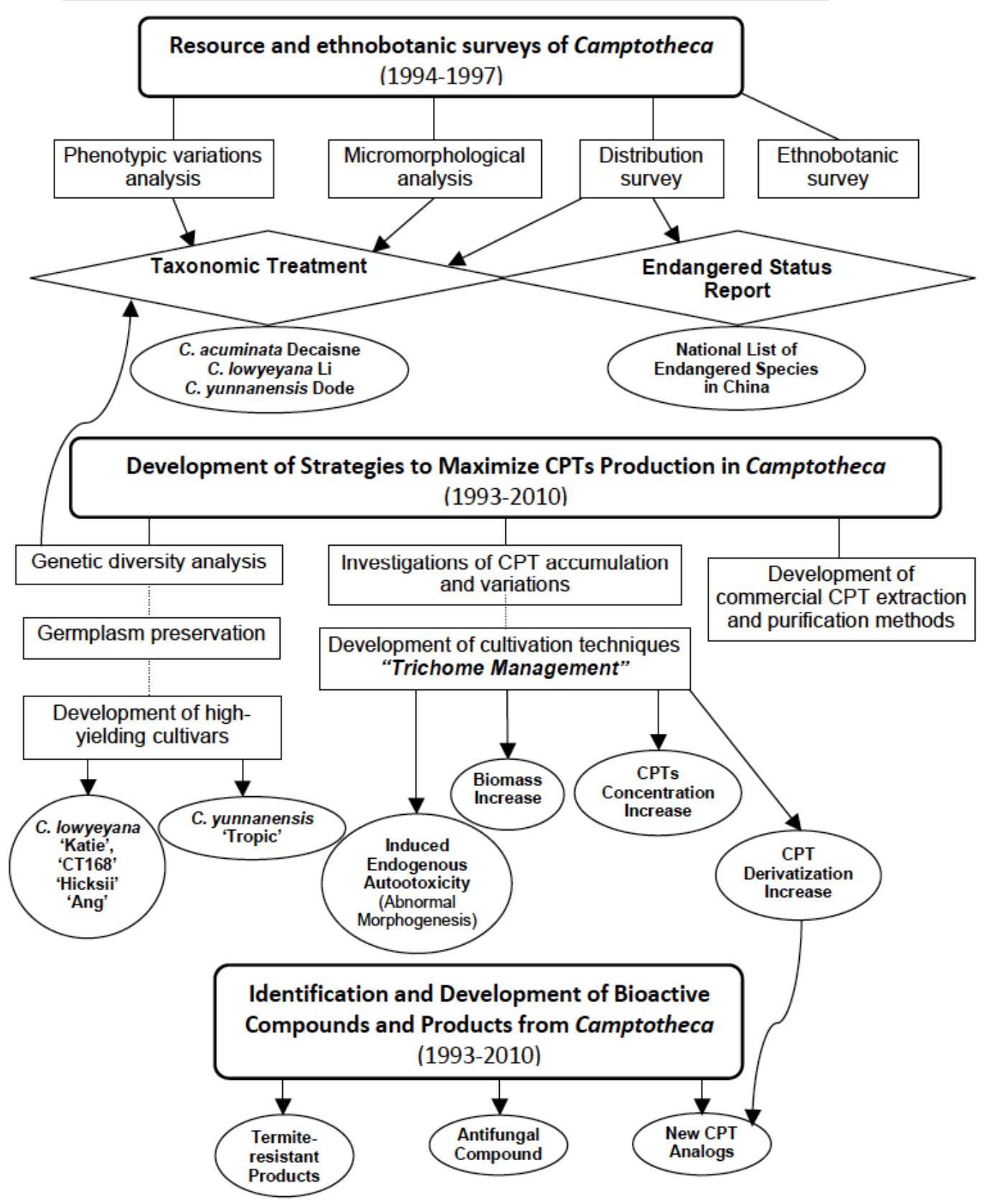

Fig. (2). Strategies to develop Camptotheca as pharmaceutical crops at the National Center for Pharmaceutical Crops, Arthur Temple College of Forestry and Agriculture, Stephen F. Austin State University, Nacogdoches, Texas, USA.

To solve the above problems, researchers at National Center for Pharmaceutical Crops, Arthur Temple College of Forestry and Agriculture, Stephen F. Austin State University began our Camptotheca research project in the early 1990s. The financial support has been received from the Houston Livestock Show and Rodeo, the Fondren Foundation, Stephen F. Austin State University, Chinese Ministry of Forestry, David Dolben, Jack Hicks, and Charles Poland. To develop Camptotheca as pharmaceutical crops, the studies have been conducted in four aspects from 1993 to 2010 (Fig. 2):
1. Evaluation of the potential of CPTs as anti-cancer and anti-viral drugs [1] (1993-1994).

2. Investigation of the Camptotheca resource worldwide, including distribution (identification of its endangered status), phenotypic variations, micromorphological analysis, taxonomic treatment (the discovery and description of new species) [6], and ethnobotanical survey (1994-1997).

3. Development of strategies to maximize CPTs production in Camptotheca, including the establishment of an exclu- 
sive germplasm preserve, the detection of genetic diversity with DNA RAPD markers, the development of a high-CPT-yielding cultivar [23], the discovery of CPT accumulation sites in trees [24], strategy development for induced production of CPT in plants [25], discovery of induced endogenous autotoxicity (abnormal morphogenesis) following decapitation pruning [26], and the improvement of CPT extraction methods (1993-2010).

4. Identification of new bioactive compounds and products, including isolation of new anti-tumor CPT analogs [27], identification of new antifungal compounds [28, 29], development of termite control products [30] (1997-2010).

This special issue primarily includes unpublished research data in taxonomy, phenotypic and micromorphological variations, anatomy, genetic variations, distribution, ethnobotany, cultivar development, and trichome management and overview of chemical composition at National Center for Pharmaceutical Crops, Arthur Temple College of Forestry and Agriculture, Stephen F. Austin State University. These articles may provide useful data fundamental to the conservation of the species as well as various strategies to develop and manage Camptotheca as pharmaceutical crops. This special issue will also include research report on other plant sources of CPTs at the University of Puerto Rico.

\section{CONFLICT OF INTEREST}

The authors confirm that this article content has no conflict of interest.

\section{ACKNOWLEDGEMENTS}

Our Camptotheca research projects have been sponsored mainly by Stephen F. Austin State University, the Houston Livestock Show and Rodeo (HLSR) (Houston, TX), the Fondren Foundation (Houston, TX). The field surveys in China (December 1994-March 1995, December 1996January 1997, July-November 1997) were co-sponsored by the Ministry of Forestry of P.R. China and Northeast Forestry University (Harbin, China). The field surveys in China received support from the forestry departments of Guangdong, Hunan, Shaanxi, Sichuan, and Yunnan provinces, Huaiji Forestry Bureau of Guangdong, Dakengshan Forestry Farm in Huaiji of Guangdong, Guangning Forestry Bureau of Guangdong, Forestry Bureau of Dali and Xishuangbanna Nature Preserve of Yunnan, Forestry Bureau of Pengzhou City of Sichuan, Sichuan Academy of Forest Sciences, and Yunnan Academy of Forest Sciences. The greenhouse work is partly supported by the XyloMed Research Foundation (Monroe, LA). We appreciate the support of the directors and administrators of the above organizations.

Our special thanks go to Dr. Z. Cao (Stehlin Foundation for Cancer Research, Houston, TX) for providing analytical standards of CPT, CZ112, and 9-NC (Rubitecan) and Dr. J.P. McGovern (Clinical Research Manager, Clinical Development-Oncology, Pharmacia \& Upjohn, Inc., Kalamazoo, MI) for providing the analytical standard of CPT-11 (Campto$\operatorname{sar}^{\circledR}$ ) for our research work; Dr. S.J. Owens (Royal Botanical Gardens, Kew, UK), Dr. G.F. Russell (National Museum of Natural History, Smithsonian Institution, Washington D.C.), Dr. J. C. Solomon (Missouri Botanical Garden, St. Louis,
MO), Dr. P. Sunding (Botanical Museum, University of Oslo, Oslo, Norway), Dr. E. W. Wood and Dr. D.E. Boufford (Harvard University Herbaria, Cambridge, MA), and Dr. A. R. Vickery (The Natural History Museum, London, UK) as well as curators of Royal Botanical Garden (Edinburgh, Scotland), Laboratoire de Phanerogamie of Museum National d'Histoire Naturelle (Paris, France), and Botanical Museum and Library of the University of Copenhagen (Copenhagen, Denmark) for specimen loans; Dr. C.T. Kimber (Texas A \& M University), Dr. H. Switzer (Genetic Resource Center, USDA Forest Service, Chico, CA), Dr. K. Musial (Huntington Botanical Garden, CA), M. Minnaar (Nacogdoches, TX), and D. Schellenberg (Nacogdoches, TX) for providing seeds or references; B. Cunningham (Nacogdoches, TX) for providing line drawings; Dr. D.L. Creech and Dr. D. L. Kulhavy (Stephen F. Austin State University), Dr. L. Kaplan (University of Massachusetts), Dr. D. E. Soltis (Washington State University), Dr. S. R. Manchester (University of Florida), and an anonymous reviewer for their critical comments and invaluable suggestions on some manuscripts; P. R. Blackwell (SFA College of Forestry), A. Nuruddin (Malaysia), and L. Liu for assistance in remote sensing application and SAS analyses; D. Chen (Forestry Bureau, Huaiji County, Guangdong, China) for their support of our field survey; D. Stover, A. Kulhavy, M. Welch, and S. Schoelter (Stephen F. Austin State University) and M. Adams (East Texas Plant Materials Center, Nacogdoches, TX) participated in the greenhouse and field trials

Finally, I am greatly indebted to Dr. K.T. Adair, Dr. R.S. Beasley, and Dr. S.H. Bullard (Stephen F. Austin State University), C. Poland (Lufkin, TX), J. Hicks (Lufkin, TX), L.R. Lowrey (Houston, TX), K. and T. Northrup (Houston, TX) for their support and encouragement. This work would not have been possible without their efforts.

Specimen examined for plant taxonomy are deposited in the following herbaria: A, ASTC, BM, C, CDBI, E, HNNU, IBSC, K, KUN, MO, O, P, PE, SZ, US, and WUK. Voucher specimen used for chemical analysis are deposited in the National Center for Pharmaceutical Crops, Arthur Temple College of Forestry and Agriculture, Stephen F. Austin State University.

\section{PATIENT'S CONSENT}

Declared none.

\section{REFERENCES}

[1] Li, S. Y.; Adair, K. T. Camptotheca acuminata Decaisne, Xi Shu, A Promising Anti-tumor and Anti-viral Tree for the 21st Century. Henry M. Rockwell Monograph, Stephen F. Austin State University: Nacogdoches, 1994.

[2] Priel, E.; Aflalo, E.; Chechelnitsky, G.; Benharroch, D.; Aboud M.; Segal, S. Inhibition of retrovirus-induced disease in mice by camptothecin. J. Virol., 1993, 67 (6), 3624-3629.

[3] Wall, M. E.; Wani, M. C.; Cook, C. E.; Palmer, K. H.; McPhail, A. T.; Sim, G. A. Plant antitumor agents. I. The isolation and structure of Camptothecin, a novel alkaloidal leukemia and tumor inhibitor from Camptotheca acuminata. J. Am. Chem. Soc., 1966, 88, 38883890.

[4] Fang, W. P.; Soong, T. P. Praecursores flora Nyssacearum Sinensium. Acta Phytotax. Sin., 1975, 13, 83-89.

[5] Fang, W. P.; Zhang, Z. R. Flora Reipublicae Popularis Sinicae. Science Press: Beijing, 1983. 
[6] LI, S. Y. Camptotheca lowreyana, a new species of anti-cancer happytrees. Bull. Bot. Res., 1997, 17 (3), 348-352.

[7] Eyde, R. H. Morphological and paleobotanical studies of the Nyssaceae. I. The modern species and their fruits. J. Arnold Arb., 1963, 44, 1-59.

[8] Van der Burgh, J. Studies in woody anatomy of the family Nyssaceae. J. Elisha Mitchell Sci. Soc., 1949, 65, 245-261.

[9] Cheng, J. Q.; Liu, J. J.; Liu, P. Woods of China. China Forestry Press: Beijing, 1992.

[10] Zhang, R. H.; Liu, H. E.; Wang, Z. T. Seedling morphology of important trees in China. Science Press: Beijing, 1993.

[11] Eyde, R. H. Comprehending Cornus: Puzzles and progress in the systematics of the dogwoods. Bot. Rev., 1988, 54, 233-351.

[12] Wen, J.; Stuessy, T. F. The phylogeny and biogeography of Nyssa (Cornaceae). Syst. Bot., 1993, 18, 68-79.

[13] Xiang, Q. Y.; Soltis, D. E.; Morgan, D. R.; Soltis, P. S. Phylogenetic relationships of Cornus L. sensu lato and putative relatives inferred from rbcL sequence data. Ann. Miss. Bot. Gard., 1993, 80, 723-734.

[14] Chen, L. J. The comparative embryological study and proposed addinity of Camptotheca, Nyssa, and Davidia. Beijing Institute of Botany: Chinese Academy of Sciences, Beijing, 1988.

[15] Li, L. C.; Hsu, P. S. Chromosome observations of eight species endemic to China. Acta Phytotax. Sin., 1986, 24, 157-160.

[16] Chen, L. J.; wang, F. H.; Wu, Y. R. The pollination biology of Camptotheca acuminata Decne. (Nyssaceae). Cathaya, 1991, 3, 45-52.

[17] Smith, R. L. Camptotheca acuminata, biography of camptothecin, a promising cancer drug. Lasca Leaves, 1969, (9-10), 55-59.

[18] Tanai, T. Fossil leaves of the Nyssaceae from the Miocene of Japan. J. Faculty Sci. Hokkaido Univ. IV. Geol. Mineral., 1977, 17, 505-516.
[19] Suzuki, M. Two new species of Nyssaceous fossil woods from the palaeogene of Japan. J. Jpn. Bot., 1976, 50, 228-238.

[20] Lopez-Meyer, M.; Nessler, C. L.; McKnight, T. D. Sites of accumulation of the antitumor alkaloid camptothecin in Camptotheca acuminata. Planta Med., 1994, 60, 558-560.

[21] Liu, Z.; Adams, J. Camptothecin yield and distribution within Camptotheca acuminata trees cultivated in Louisiana. Can. J. Bot. 1996, 74, 360-365.

[22] Jain, A. K.; Nessler, C. L. Clonal propagation of Camptotheca acuminata through shoot bud culture. Plant Cell Tiss. Org. Cult., 1996, 44, 229-233.

[23] Li, S. Y. Camptotheca lowreyana cultivar named 'Katie'. U.S. Patent PP11,959P, 2001.

[24] Li, S. Y.; Yi, Y. J.; Wang, Y. J.; Zhang, Z. Z.; Beasley, R. S. Camptothecin accumulation and variation in Camptotheca Decaisne. Planta Med., 2002, 68 (11), 1010-1016.

[25] Li, S. Y. A system for increasing the production of indole and quinoline alkaloids, particularly camptothecins and related compounds, from plants. R.O. China Invention 162720, 2002.

[26] Li, S. Y.; Wang, P.; Yuan, W. Induced endogenous autotoxicity in Camptotheca. Front. Biosci., 2010, E2, 1196-1210.

[27] Zhang, Z. Z.; Li, S. Y.; Zhang, S. M.; Liang, C.; Gorenstein, D.; Beasley, R. S. New Camptothecin and ellagic acid analogues from the root bark of Camptotheca acuminata. Planta Med., 2004, 70 (12), 1216-1221.

[28] Li, S. Y.; Zhang, Z. Z.; Cain, A.; Wang, P.; Long, M.; Taylor, J. Anti-fungal activity of camptothecin, trifolin, and hyperoside isolated from Camptotheca acuminata. J. Agric. Food Chem., 2005 53, 32-37.

[29] Li, S. Y. Methods for inhibiting fungal pathogen infestation and propogation. Patent US $20070134282 \mathrm{~A} 1, \mathbf{2 0 0 7}$

[30] Li, S. Y. Utilizing Camptotheca products for termite control. Patent WO 2002000020 A3. 2003.

Received: December 30, 2013

Revised: September 16, 2014

Accepted: September 24, 2014

(C) Shiyou Li; Licensee Bentham Open.

This is an open access article licensed under the terms of the Creative Commons Attribution Non-Commercial License (http://creativecommons.org/licenses/by-nc/3.0/) which permits unrestricted, non-commercial use, distribution and reproduction in any medium, provided the work is properly cited. 